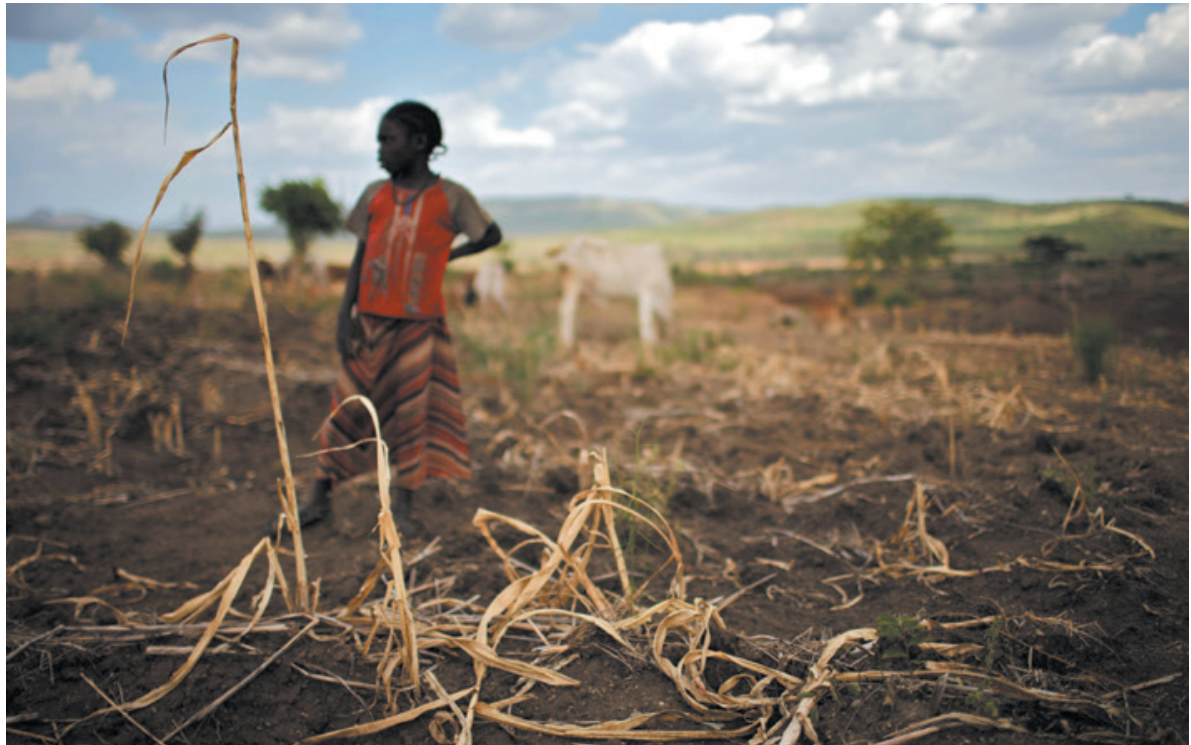

Loss of crops to drought contributed to a food crisis in Ethiopia in 2008.

\title{
AGRICULTURE
}

\section{Cross-bred crops get fit faster}

\section{Genetic engineering lags behind conventional breeding in efforts to create drought-resistant maize.}

\section{BY NATASHA GILBERT}

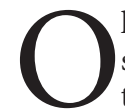
ld-fashioned breeding techniques seem to be leading genetic modification in a race to develop crops that can withstand drought and poor soils.

As the climate warms and rainfall becomes more erratic, farmers worldwide will increasingly need crops that can thrive in drought conditions. And the high costs of fertilizers - along with the environmental damage they can cause - are also pushing farmers to look for crop varieties that can do more with less.

The need for tougher crops is especially acute in Africa, where drought can reduce maize (corn) yields by up to $25 \%$. The Drought Tolerant Maize for Africa project, which launched in 2006 with US\$33 million, has developed 153 new varieties to improve yields in 13 countries. In field trials, these varieties match or exceed the yields from commercial seeds under good rainfall conditions, and yield up to $30 \%$ more under drought conditions.

An analysis published earlier this year reported that by the project's end in 2016, the extra yields from drought-tolerant maize could help to reduce the number of people living in poverty in the 13 countries by up to $9 \%$
(R. La Rovere et al. J. Dev. Areas 48, 199-225; 2014). In Zimbabwe alone, that effect would reach more than half a million people.

The project's success is due in large part to its access to a large seed bank managed by one of its partners, the International Maize and Wheat Improvement Center (CIMMYT) in Mexico City. Breeders from CIMMYT and the International Institute for Tropical Agriculture in Ibadan, Nigeria, searched the collection for maize varieties that thrive in water-scarce regions. The researchers cross-bred these varieties and then mated the most droughttolerant of their offspring. Several cycles of this process led to seed that was better adapted to water-scarce conditions. In a final step, project scientists cross-bred these plants with varieties that have been successful in Africa.

"It is a painstaking and expensive process," says Kevin Pixley, director of CIMMYT's genetic resources programme.

The CIMMYT researchers established that certain characteristics predict how a maize plant will fare in drought. One of the most telling is the number of days between when the plant's male organs shed pollen and when the female silks emerge. When water is scarce, the silks emerge late. If the delay is long enough, they emerge after the plants have released their pollen and are not fertilized.

"Finding out this relationship was very important to be able to select for drought tolerance," says Pixley. By favouring plants with shorter intervals between pollen release and silk emergence, breeders were able to produce maize that was more resistant to drought.

Drought tolerance is a complex trait that involves multiple genes. Transgenic techniques, which target one gene at a time, have not been as quick to manipulate it. But CIMMYT and six other research organizations are also developing genetically modified (GM) varieties of drought-resistant maize, in collaboration with agricultural biotechnology giant Monsanto in St Louis, Missouri. Coordinated by the African Agricultural Technology Foundation in Nairobi, the Water Efficient Maize for Africa project aims to have a transgenic variety ready for African farmers by 2016 at the earliest.

Like drought resistance, maize's ability to grow in nitrogen-poor soils is genetically complex, and the need for varieties that do well with little fertilizer is pressing. Most African farmers can afford only one-tenth the amount of fertilizer recommended for their crops. This is one of the biggest problems they face, says Biswanath Das, a maize breeder at CIMMYT.

Researchers at CIMMYT are working to address that problem through the Improved Maize for African Soils (IMAS) project, a collaboration with the Kenya Agricultural Research Institute in Nairobi; the South African Agricultural Research Council in Pretoria; and DuPont Pioneer in Johnston, Iowa. The 10-year, US\$19.5-million project is pursuing conventional and transgenic approaches.

Since its launch in 2010, IMAS has developed 21 conventionally bred varieties. Over the next year the project's leaders hope to commercialize these varieties and introduce them in eight countries. In field tests, IMAS varieties yielded up to 1 tonne per hectare more in nitrogen-poor soils than did commercially available varieties. By contrast, the project's researchers say that they are at least 10 years from developing a comparable GM variety.

Conventional breeding will probably have a greater impact, says Das, "but it is important to consider all options".

\section{CORRECTIONS}

The News Feature 'Survival of the fittest' (Nature 513, 157-159; 2014) referred to the wrong Possession Island. The penguin work was done on the French Base d'Alfred Faure in the Crozet archipelago.

The World View by Casparus J. Crous

(Nature 513, 7; 2014) implied that Saudi Arabian scientists on highlycited.com were all at a single university. In fact, most were at one institution but several came from three other universities in Saudi Arabia. 